\title{
LOW-INTENSITY PULSED ULTRASOUND STIMULATES CELL PROLIFERATION, PROTEOGLYCAN SYNTHESIS AND EXPRESSION OF GROWTH FACTOR-RELATED GENES IN HUMAN NUCLEUS PULPOSUS CELL
}

\author{
Yuka Kobayashi ${ }^{1}$, Daisuke Sakai ${ }^{1,2^{*}}$, Toru Iwashina ${ }^{1,2}$, Sadahiro Iwabuchi ${ }^{3}$, and Joji Mochida ${ }^{1,2}$ \\ ${ }^{1}$ Department of Orthopaedic Surgery, Surgical Science, \\ ${ }^{2}$ Research Center for Regenerative Medicine, Tokai University School of Medicine, 143 Shimokasuya, Isehara, \\ Kanagawa, 259-1193, Japan \\ ${ }^{3}$ Bio-medical Engineering Laboratories, Tejin Pharma Ltd., 3-2, Asahigaoka, 4-chome, Hino, Tokyo, 191-8512, Japan
}

\begin{abstract}
Low-intensity pulsed ultrasound (LIPUS) stimulation has been shown to effect differentiation and activation of human chondrocytes. A study involving stimulation of rabbit disc cells with LIPUS revealed upregulation of cell proliferation and proteoglycan (PG) synthesis. However, the effect of LIPUS on human nucleus pulposus cells has not been investigated. In the present study, therefore, we investigated whether LIPUS stimulation of a human nucleus pulposus cell line (HNPSV-1) exerted a positive effect on cellular activity. HNPSV-1 cells were encapsulated in $1.2 \%$ sodium alginate solution at $1 \times 10^{5}$ cells/ml and cultured at 10 beads/ well in 6-well plates. The cells were stimulated for $20 \mathrm{~min}$ each day using a LIPUS generator, and the effects of LIPUS were evaluated by measuring DNA and PG synthesis. Furthermore, mRNA expression was analyzed by cDNA microarray using total RNA extracted from the cultured cells. Our study revealed no significant difference in cell proliferation between the control and the ultrasound treated groups. However, PG production was significantly upregulated in HNPSV cells stimulated at intensities of 15, 30, 60 , and $120 \mathrm{~mW} / \mathrm{cm}^{2}$ compared with the control. The results of cDNA array showed that LIPUS significantly stimulated the gene expression of growth factors and their receptors (BMP2, FGF7, TGFßR1 EGFRF1, VEGF). These findings suggest that LIPUS stimulation upregulates $P G$ production in human nucleus pulposus cells by the enhancement of several matrix-related genes including growth factor-related genes. Safe and non-invasive stimulation using LIPUS may be a useful treatment for delaying the progression of disc degeneration.
\end{abstract}

Keywords: LIPUS, ultrasound, intervertebral disc, growth factor.

\footnotetext{
"Address for correspondence

Department of Orthopaedic Surgery/Surgical Science, Tokai University School of Medicine, 143 Shimokasuya, Isehara, Kanagawa, 259-1193, Japan Telephone Number: +81463931121 FAX Number: +81463964404 E-mail: daisakai@is.icc.u-tokai.ac.jp
}

\section{Introduction}

Lower back pain is a common medical and social problem in the modern world. Therefore, there is an increasing interest in the development of new techniques for treating this problem. Since degeneration of the intervertebral disc is thought to have a close relationship with lower back pain, any strategy for delaying this degenerative process is of considerable clinical relevance (Gruber and Hanley, 1998; Phillips et al., 2003).

Based on the fact that loss of cells and cell function in the nucleus pulposus is one of the most significant factors in disc degeneration, several studies have been reported with the aim of developing therapeutic techniques for this condition. These methods have included administration of bone morphogenetic protein-2 (BMP-2) and osteogenic protein-1 (OP-1; BMP-7) to increase the ability of disc cells to synthesize proteoglycans and collagen (Yoon et al., 2003; Masuda et al., 2003), transfer of the transforming growth factor-betal (TGF- $\beta 1$ ) gene into nucleus cells using a viral vector (Nishida et al., 1998), direct injection of collagen or a proteoglycan-like construct into the discs (Klein et al., 2003), implantation of an artificial nucleus pulposus or disc (Mizuno et al., 2004; Alini et al., 2003) and implantation of mesenchymal stem cells into the discs (Sakai et al., 2006).

Low-intensity pulsed ultrasound (LIPUS) has been shown clinically to be an effective noninvasive method for the stimulation of bioactivity (Duarte, 1983; Warden, 2000; Mayr et al., 2000; Nolte et al., 2001; Gebauer et al., 2005). In an attempt to prevent disc degeneration and to find new techniques for maintaining disc function, we performed an experiment to determine whether LIPUS stimulation has any effect on the biological properties of disc cells, and found that LIPUS stimulation upregulates cell proliferation and proteoglycan (PG) synthesis in rabbit disc cells (Iwashina et al., 2006). However, no study has yet confirmed the influence of LIPUS on human disc cells. The present study was therefore performed to verify whether LIPUS could stimulate disc cell proliferation and PG production in human nucleus pulposus cells using HNPSV-1, a cell line derived from human nucleus pulposus cells which maintains the original three-dimensional architecture of the cells and their gene expression profile (Sakai et al., 2004). Furthermore, if LIPUS does upregulate cell proliferation and PG production in HNPSV-1 cells, changes in the expression of growth factor-related and matrix interaction-related genes were examined by cDNA microarray, in order to clarify the factors participating in LIPUS-induced upregulation, while real-time 
PCR was used to quantify the changes in growth factor related gene expression.

\section{Materials and Methods}

\section{Cell isolation and culture}

The HNPSV-1 cells, cryopreserved in liquid nitrogen, were quickly thawed. The isolated cells were seeded in 6-well culture plates (Primaria, BD, Franklin Lakes, NJ, USA) at cell densities of $3.2 \times 10^{4} \mathrm{cells} / \mathrm{cm}^{2}$ in Dulbecco's modified Eagle medium (DMEM, Gibco; Life Technologies, Carlsbad, CA, USA) with 10\% fetal bovine serum (FBS, Gibco), penicillin $(100 \mu \mathrm{g} / \mathrm{ml})$ and streptomycin (250 ng/ $\mathrm{ml})$ at $37^{\circ} \mathrm{C}$, in a $5 \% \mathrm{CO}_{2}$ atmosphere.

\section{Culture of HNPSV-1 cells in alginate}

After three passages, the cultured cells were detached with trypsin-EDTA solution ( $0.05 \%$ trypsin, Gibco) and counted using a haemocytometer. The cells were collected by centrifugation and resuspended in $1.2 \%$ low-viscosity alginate (Clonetics; Lonza, Basel, Switzerland) in $0.15 \mathrm{M}$ sodium chloride at a concentration of $1 \times 10^{5}$ cells $/ \mathrm{ml}$. The cell suspension was gently expressed through an 18-gauge needle attached to a $1-\mathrm{ml}$ syringe into a $102 \mathrm{mM}$ calcium chloride solution (Clonetics) to form drops of semisolid beads. After 10 min of polymerization, the beads were washed three times with normal saline, and then three more times with DMEM. Ten beads were placed in each well of a 6-well plate (non-treated, Iwaki, Japan) and then incubated in DMEM (4.5 ml/well) supplemented with $10 \%$ FBS and penicillin $(100 \mu \mathrm{g} / \mathrm{ml})$ and streptomycin $(250 \mathrm{ng} /$ $\mathrm{ml})$ at $37^{\circ} \mathrm{C}$, in a $5 \% \mathrm{CO}_{2}$ atmosphere.

\section{Ultrasound stimulation}

We upgraded SAFHS (Sonic Accelerated Fracture Healing System; Tejin Pharma Ltd, Tokyo, Japan) as a special US generator, and it was used to deliver an ultrasound (US) signal with a spatial and temporal average intensity of 7.5, $15,30,60$, or $120 \mathrm{~mW} / \mathrm{cm}^{2}$. The frequency was $1.5 \mathrm{MHz}$ with a $200-\mu$ s tone burst repeated at $1.0 \mathrm{kHz}$. Each 6-well plate of the LIPUS group was placed on an ultrasonic transducer (Iwabuchi et al., 2005). The volume of culture medium in each well was reduced to $4 \mathrm{ml}$ to avoid spillage. After the plate cover had been removed, an anti-reflection chamber was placed in each well while taking care to avoid intoducing air bubbles. It was confirmed that the alginate beads were not compressed by the chamber. Coupling gel (Sono Jelly, Toshiba, Tokyo, Japan) was dripped onto all the transducers, and the output was confirmed using an output checker. Then the culture plate and chamber unit were set on the transducer, and stimulation with LIPUS was started. For cell proliferation and PG production studies, the cells in the US group were stimulated for 20 min each day at a multiple range of intensity $(7.5,15,30,60,120$ $\mathrm{mW} / \mathrm{cm}^{2}$ ) for five or twelve days, starting on the third day after seeding in alginate. Later, to evaluate the effect of LIPUS on gene expression, the intensity of LIPUS was fixed at $30 \mathrm{~mW} / \mathrm{m}^{2}$, which was the level confirmed to provide the greatest production of proteoglycan. The control plates were handled in the same manner without LIPUS, i.e., the cover of each plate was removed, a chamber was placed in each well, and the plate was left to stand at room temperature for $60 \mathrm{~min}$ under the same conditions.

\section{Measurement of DNA synthesis}

DNA synthesis was examined by uptake of $\left[{ }^{3} \mathrm{H}\right]$-thymidine. At days 5 and 12 after the daily ultrasonic stimulation, the medium in each plate was changed to complete medium containing $\left[{ }^{3} \mathrm{H}\right]$-thymidine at a concentration of $2 \mu \mathrm{Ci} /$ $\mathrm{ml}$. At $18 \mathrm{~h}$ after the start of the labelling, the beads were washed twice in PBS and added to sodium citrate solution ( $55 \mathrm{mM}$, in $90 \mathrm{mM} \mathrm{NaCl}$ ). The beads were dissolved and the two compartments [cell-associated matrix (CM) and further removed matrix (FRM)] were separated by mild centrifugation at $100 \times \mathrm{g}$ for $10 \mathrm{~min}$ at $4^{\circ} \mathrm{C}$. Then $10 \%$ trichloroacetic acid (TCA) was added to each fraction. The fractions were centrifuged (3000 rpm for $10 \mathrm{~min}$ ), and the supernatant (TCA) was removed. This procedure was repeated 5 times, and TCA-insolvable material was collected and dried with $70 \%$ ethanol. The dry material was treated overnight with $1 \mathrm{ml}$ of solvent (Solvable $^{\mathrm{TM}}$; Packard, Meriden, CT, USA) at $45^{\circ} \mathrm{C}$, and $10 \mathrm{ml}$ of liquid scintillation cocktail (AtomlightTM; Packard) was added for counting of emissions (Beckman LS4800, Fullerton, CA, USA). Radioactivity [in disintegrations per minute (dpm)] was divided by the amount of DNA calculated using the Hoechst33258 dye method. All the isotope experiments were repeated more than two times.

\section{Measurement of PG synthesis}

Incorporation of $\left[{ }^{35} \mathrm{~S}\right]$-sulphate was used to measure PG synthesis. At the indicated times, cultures were labelled by transfer to complete medium containing $\left[{ }^{35} \mathrm{~S}\right]$-sulphate at a concentration of $40 \mu \mathrm{Ci} / \mathrm{ml}$ for $18 \mathrm{~h}$. Subsequent PBS washes, dissolution of alginate, TCA treatment, drying, and scintillation counting were carried out using the same procedure as those for $\left[{ }^{3} \mathrm{H}\right]$-thymidine uptake.

\section{Measurement of DNA content}

DNA content was measured using the fluorometric method as described previously. On days 0, 5 and 12 after US stimulation, beads in each well were collected and dissolved in sodium citrate solution ( $55 \mathrm{mM}$, in $90 \mathrm{mM} \mathrm{NaCl}$ ) for 10 $\min$ at $4^{\circ} \mathrm{C}$. After centrifugation, separated $\mathrm{CM}$ fractions were digested for $18 \mathrm{~h}$ at $55^{\circ} \mathrm{C}$ in papain solution $(20 \mu \mathrm{g} / \mathrm{ml}$ in $50 \mathrm{mM}$ EDTA, $5 \mathrm{mM}$ L-cystein). Then $100 \mu \mathrm{l}$ of Hoechst 33258 dye solution $(1 \mu \mathrm{g} / \mathrm{ml}$, pentahydrate, Molecular Probes, Eugene, OR, USA) was mixed with the digested sample, and $2 \mathrm{~h}$ later the emission spectrum of the mixture was determined for excitation at $365 \mathrm{~nm}$ by measuring the fluorescence emission of $460 \mathrm{~nm}$ using a plate reader (FL500, Bio-Tek, Highland Park, VT, USA). The standard curve was determined using known concentrations of calf thymus DNA (Sigma, St. Louis, MO, USA).

\section{Measurement of $P G$ content}

PG content was measured by dimethylmethylene blue (DMMB, Polysciences, Warrington, PA, USA) assay. On days 5 and 12 after starting US, the beads were harvested, dissolved, and the two matrix compartments, CM and FRM, were separated as described above. Each fraction 
was digested with papain (concentration of papain: $\mathrm{CM}$; $20 \mu \mathrm{g} / \mathrm{ml}, \mathrm{FRM} ; 40 \mu \mathrm{g} / \mathrm{ml}$ ) at $55^{\circ} \mathrm{C}$ for $18 \mathrm{~h}$. The digested sample solution $(75 \mu \mathrm{l})$ was mixed with $25 \mu \mathrm{l}$ of $2.88 \mathrm{M}$ $\mathrm{GuHCl}$ solution and $200 \mu \mathrm{l}$ of DMMB reagent in a 96well plate and immediately the absorbance at $530 \mathrm{~nm}$ and $595 \mathrm{~nm}$ was measured using a plate reader (SPECTRA MAX250, Molecular Devices, MDS, Toronto, Canada). Purified bovine nasal septum-D1 PG (Sigma) was used as a standard, and the $530 \mathrm{~nm} / 595 \mathrm{~nm}$ ratio was calculated. The total amount of PG per well was normalized versus the total amount of DNA per well.

\section{Harvesting of cells for RNA isolation}

After completing the LIPUS treatment, 10\% FBS was injected into each well twice to wash out the medium. Then the beads in each well were transferred to a conical tube with a spoon, stirred with $55 \mathrm{mM}$ sodium citrate in $90 \mathrm{M} \mathrm{NaCl}$, and cooled to $4^{\circ} \mathrm{C}$. The tube was centrifuged after $30 \mathrm{~min}$ to separate three layers, which comprised a white bottom layer and a middle layer composed of alginate beads with cells, as well as a top layer composed of alginate beads without cells. The top layer was discarded and then the same procedure was repeated to collect the cells in the beads.

\section{SV Total RNA Isolation System}

Total RNA was isolated using an SV Total RNA Isolation System (Promega R, Madison, WI, USA) according to the protocol provided by the manufacturer. An SV RNA lysis buffer was added to the harvested cells, and the mixture thus obtained was homogenized by repeated pipetting with a 20 -gauge needle. The homogenate was mixed with SV RNA dilution buffer, centrifuged, and then heated at $70^{\circ} \mathrm{C}$ for $3 \mathrm{~min}$. The supernatant thus obtained was collected, mixed with $95 \%$ ethanol, and centrifuged with a spin column to extract total RNA. After the RNA was isolated, genomic DNA was removed using DNAse (Qiagen, Venlo, The Netherlands).

\section{Complementary DNA microarray}

RNA extracted from the cells of the LIPUS group treated with $30 \mathrm{~mW} / \mathrm{m}^{2}$ of ultrasound for three days and from the cells of the control group was used to synthesize cDNA. The targets were prepared using the Atlas Glass Fluorescent Labelling Kit (Clontech Laboratories, Mountain View, CA, USA). This kit provides for indirect, "two-step" labelling of the target cDNA. Two-step labelling typically incorporates higher levels of label than direct, single-step procedures that directly incorporate fluorescently tagged nucleotides during cDNA synthesis. Target preparation began with $20 \mu \mathrm{g}$ of total RNA. Aminoallyl-dUTP was incorporated during first-strand cDNA synthesis. Fluorescent dye (Cy3 or Cy5) was covalently coupled to aminoallyl-dUTP in the first-strand cDNA. The resulting labelled cDNA was purified using the Atlas NucleoSpin Extraction Kit (Clontech). The absorbance of each target was determined by optical density measurements at $260 \mathrm{~nm}$ (DNA) and either $550 \mathrm{~nm}$ (Cy3) or $650 \mathrm{~nm}$ (Cy5). The total dye content (pmoles), amount of probe (ng), and specific activity (number of Cy molecules incorporated/number of bases) was calculated for each target synthesized. The optimal incorporation of dye ranged from 20 to 50 covalently linked dye per 1000 nucleotides. Hybridization of the targets was performed using the Atlas ${ }^{\mathrm{TM}}$ Glass Array Human 1.0K Microarray (Clontech) technique to analyze the expression of 1101 spotted genes based on their fluorescence intensity. The slides were hybridized overnight at $50^{\circ} \mathrm{C}$. Following hybridization, slides were washed, dried and then scanned using a ScanArray 5000XL laser scanner (PerkinElmer LAS, Inc., Shelton, CT, USA). The images were analyzed using QuantArray Microarray Analysis Software, Version 3.0 (Packard BioChip Technologies). Because the microarray analysis was performed in order to find factors upregulating cell proliferation and PG production, attention was focused on changes in expression of growth factor-related and matrix interaction-related genes.

\section{Real-time PCR}

Real-time PCR was performed to assess changes in expression quantitatively focusing on growth factor genes whose level of expression that showed differences of more than 1.5 fold mean signal ratio between the treated and control cultures in the above microarray analysis. Customized TaqMan probes for the designated genes whose 5'-3' ends were hybridized with a fluorescence-labelled oligonucleotide were purchased from Applied BioSystems (Carlsbad, CA, USA). In brief, cDNA was synthesized from total RNA. When the target DNA was annealed with specific oligonucleotide primers and TaqMan probes, hydrolysis occurred at the 5 ' end, followed by release of the dye, generating fluorescence. This fluorescence was used to detect and measure the expression of the genes. The sequences of the primers were obtained from the GeneBank database (National Center for Biotechnology Information Gene Bank database). Table 1 shows the sequences of the probes. ABI PRISM $7700^{\mathrm{TM}}$ Sequence Detector (Applied BioSystems) software was used for analysis, and a Gene Pix (Molecular Devices) scanner was used to measure fluorescence. The thermal cycler was set for the following conditions: $50^{\circ} \mathrm{C}$ for 1 min during Stage $1,60^{\circ} \mathrm{C}$ for $30 \mathrm{~min}$ during Stage 2 , and $95^{\circ} \mathrm{C}$ for $5 \mathrm{~min}$ during Stage 3. The number of cycles was set at 40 . To provide an internal standard for correcting RNA purity, glyceraldehyde-3-phosphate dehydrogenase (GAPDH) was used as a housekeeping gene. Array Gauge diagnostic software (FujiFilm, Tokyo, Japan) was employed for analysis. This software automatically drew the amplification curve of each gene, which was combined with a threshold line to measure the threshold cycle of each gene. Then the comparative delta-delta $\mathrm{Ct}$ technique was used to quantify the relative initial concentration of each gene from the number of cycles required for amplification in relation to the logarithmic value of the initial concentration of the GAPDH standard.

\section{Statistical analyses}

All experiments were performed in triplicate. Results were expressed as mean \pm standard deviation of three experiments. Significance of differences was assessed using two-way analysis of variance (ANOVA) with Fisher's PLSD test as a post hoc test for cell proliferation and PG production analysis, with the level of significance set at 
$p<0.05$. For microarray analysis, the Mann-Whitney $U$ test was chosen to evaluate the significance of differences in expression levels because of the size and distribution of the samples in this expression study. This non-parametric two-tailed test is not based on assumptions about the distribution of expression values (e.g., normal distribution) or the equality of variance. For all tests, differences at $p<0.05$ were considered significant.

\section{Results}

\section{$\left[{ }^{3} \mathrm{H}\right]-$ Thymidine incorporation}

DNA synthesis, measured as the incorporation of $\left[{ }^{3} \mathrm{H}\right]$-thymidine (Fig. 1), was significantly increased in the $60 \mathrm{~mW} /$ $\mathrm{cm}^{2}$ and $120 \mathrm{~mW} / \mathrm{cm}^{2}$ groups compared with the control group on Day 5 of ultrasound treatment $(60 \mathrm{~mW}: 34.42$ $\times 10^{3} \mathrm{dpm} / \mu \mathrm{g}$ DNA, $p=0.0071 ; 120 \mathrm{~mW}: 33.10 \times 10^{3} \mathrm{dpm} /$ $\mu \mathrm{g}$ DNA, $p=0.0340)$. However, no significant difference was noted between the control and treated groups on Day 12.

\section{Hoechst 33258 assay}

A gradual increase of DNA through the 14-day culture period was confirmed in all of the groups (Fig. 2). There was a significant increase of DNA in the $120 \mathrm{~mW} / \mathrm{cm}^{2}$ group as compared with the control group on Days 5 and 12 of ultrasound treatment ( 5 days: $120 \mathrm{~mW}, 1.37 \mu \mathrm{g} / \mathrm{well}$, $p=0.0162$; 12 days: $120 \mathrm{~mW}, 2.66 \mu \mathrm{g} / \mathrm{well}, p=0.0162)$. As observed with respect to the incorporation of $\left[{ }^{3} \mathrm{H}\right]$-thymidine (see above), there was a significant increase of DNA due to ultrasound treatment in the $120 \mathrm{~mW} / \mathrm{cm}^{2}$ group.

\section{$\left[{ }^{35} \mathrm{~S}\right]-$ Sulphate incorporation}

Synthesis of proteoglycans, measured as the incorporation of $\left[{ }^{35} \mathrm{~S}\right]$-sulphate, was significantly increased on Day 14 compared with Day 7 (Fig. 3). Incorporation of $\left[{ }^{35} \mathrm{~S}\right]$-sulphate was significantly increased in the $7.5,15,30,60$ and $120 \mathrm{~mW} / \mathrm{cm}^{2}$ groups compared with the control group on Days 5 and 12 of ultrasound (Fig. 3). In particular, the synthesis of proteoglycans was markedly increased in the $30 \mathrm{~mW} / \mathrm{cm}^{2}$ group compared with the other groups on both Days 5 and 12 .

\section{DMMB assay}

Proteoglycans were quantified by the DMMB assay. The proteoglycan level increased as the culture period was prolonged (Fig. 4. It was significantly increased in the 15, 30,60 and $120 \mathrm{~mW} / \mathrm{cm}^{2}$ groups compared with the control group on Day 5 of ultrasound treatment (Fig. 4). It was also significantly increased in the $7.5,15,30,60$ and 120 $\mathrm{mW} / \mathrm{cm}^{2}$ groups compared with the control group on Day 12 (Fig. 4). Although the proteoglycan level was increased in all of the treated groups, there were no significant differences between any of them.

\section{Microarray analysis}

Analysis of 1101 genes showed that the expression of 846 genes in the LIPUS group was increased in comparison with the control group. Among these 846 genes, 114 (spot intensity $>70 \mathrm{x}$ control) had fluorescence intensity above

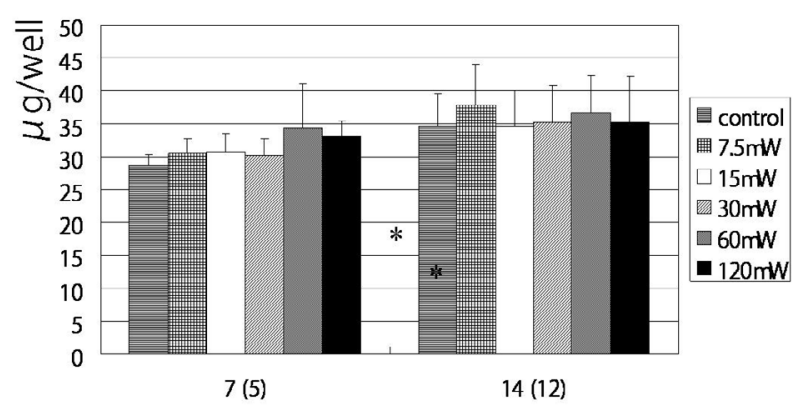

Days in culture (no. of US stimulations)

Figure 1. Cell proliferation rate is expressed as $\left[{ }^{3} \mathrm{H}\right]$-thymidine incorporation divided by DNA content per well. $\left[{ }^{3} \mathrm{H}\right]$-thymidine incorporation is significantly increased in the 60 and $120 \mathrm{~mW}$ groups compared with the control group on Day 5 of LIPUS group.

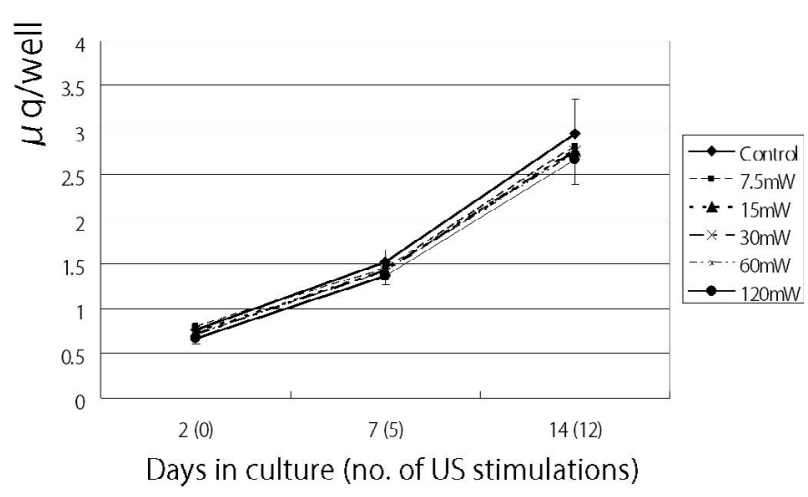

Figure 2. Cell number is represented as the DNA content per well. There was a gradual increase of DNA content through the 14-day culture period. On Day 5 and 12 after the start of ultrasound stimulation, there was a significant increase of DNA in the $120 \mathrm{~mW}$ groups compared with the control group.

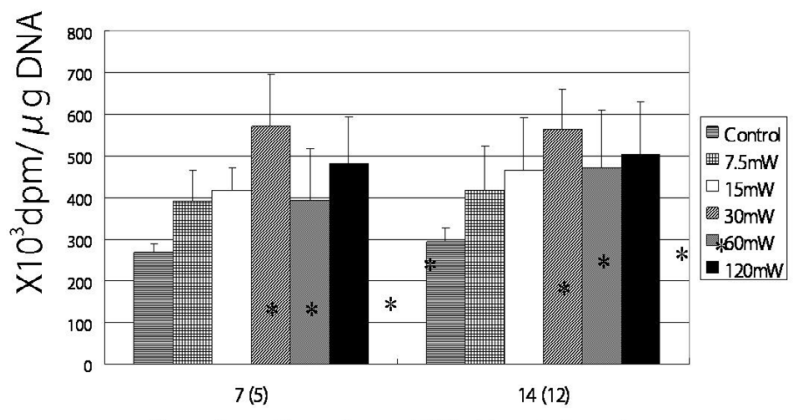

Days in culture (no. of US stimulations) $* p<0.05$

Figure 3. PG synthesis per DNA in control and LIPUS group cultures. PG synthesis is expressed as [S]-sulphate incorporation per culture over a period of $18 \mathrm{~h}$, divided by DNA content. PG synthesis significantly increased on Day 14 compared with Day 7. Regarding intensity of ultrasound, positive effect of PG synthesis was at its best at stimulation of $30 \mathrm{~mW}$. 


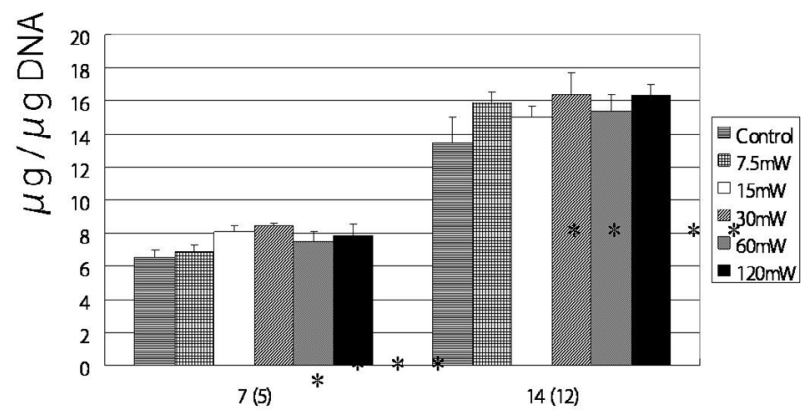

Days in culture (no. of US stimulations)

Figure 4. At 7 and 14 days of culture, PG content was measured by DMMB assay. On day 5 after the start of LIPUS stimulation, there was a significant increase in the 15,30, 60 and $120 \mathrm{~mW}$ group compared with the control group. On day 12 after the start of LIPUS stimulation, there was a significant increase in the 7.5, 15, 30, 60 and $120 \mathrm{~mW}$ groups compared with the control group.
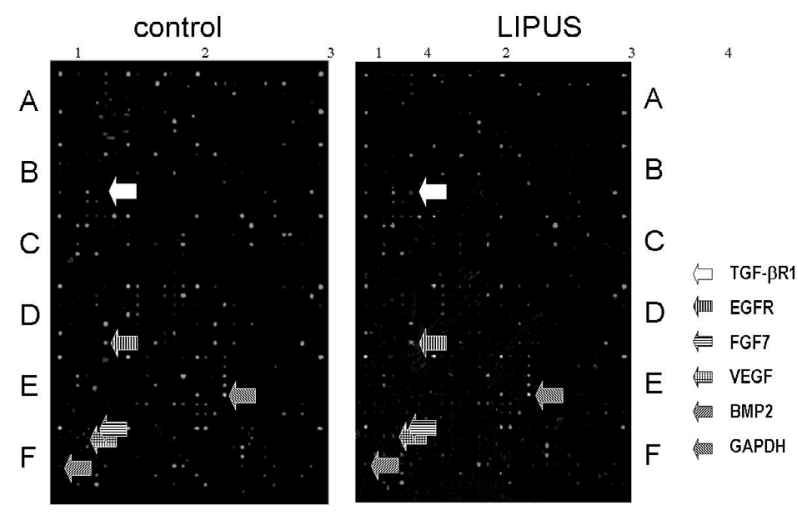

Figure 5. Gene pix showed higher signal intensity in growth factor expression in LIPUS group compared to control group.
Table 1. Microarray analysis results for growth factor and matrix related genes. Mean signal ratio in LIPUS treated group versus the control is indicated.

\begin{tabular}{|c|c|c|c|}
\hline classification & Gene & $\begin{array}{l}\text { mean } \\
\text { ratio }\end{array}$ & \\
\hline \multirow{18}{*}{ growth factor } & 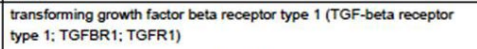 & 4.70 & $\pi \uparrow$ \\
\hline & Bone morphogenetic protein 2A (BMP2A) & 1.83 & $\pi$ \\
\hline & fibroblast growth factor 7 (FGF7): keratinocyte growth factor (KGF) & 1.82 & $\pi$ \\
\hline & epidermal growth factor receptor (EGF receptor, EGFR) & 1.82 & $\Uparrow$ \\
\hline & vascular endothelial growth factor (VEGF): vascular permeability & 1.55 & $\pi$ \\
\hline & Bone morphogenetic protein 7 (BMP7): osteogenic protein 1 (OP1) & 1.45 & $\uparrow$ \\
\hline & growth differentiation factor 15 (GDF15) & 1.45 & $\uparrow$ \\
\hline & fibroblast growth factor 8 (FGF8) & 1.44 & $\uparrow$ \\
\hline & fibroblast growth factor 8 (FGFB) & 1.35 & $\uparrow$ \\
\hline & $\begin{array}{l}\text { transforming growth factor beta receptor III (TGF beta receptor III: } \\
\text { TGFR3): betaglycan }\end{array}$ & 1.34 & $\uparrow$ \\
\hline & Bone morphogenetic protein 8 (BMP8; osteogenic protein 2 (OP2) & 1.28 & $\uparrow$ \\
\hline & insulin-like growth factor I receptor (IGF 1R) & 1.25 & $\uparrow$ \\
\hline & growth differentiation factor 1 (GDF1) & 1.23 & $\uparrow$ \\
\hline & insulin-like growth factor I(IGF 1); somatomedin C & 1.23 & $\uparrow$ \\
\hline & fibroblast growth factor 3 (FGF3) & 1.22 & $\uparrow$ \\
\hline & transforming growth factor beta (TGF-beta; TGFB) & 1.00 & $\uparrow$ \\
\hline & Bone morphogenetic protein 5 (BMP5) & 0.82 & $\downarrow$ \\
\hline & Bone morphogenetic protein 1 (BMP1) & 0.85 & 1 \\
\hline \multirow[t]{4}{*}{ proteoglycan } & Bone marrow proteoglycan 2 & 4.00 & $\pi$ \\
\hline & Bone proteoglycan II (PGS2): decorin (DCN) & 2.01 & $\Uparrow \uparrow$ \\
\hline & Bone/cartilage small proteoglycan 1 (PGS1): biglycan (BGN) & 1.03 & $\uparrow$ \\
\hline & heparan sulfate proteoglycan (HSPG2) & 1.20 & $\uparrow$ \\
\hline \multirow[t]{14}{*}{ collagen } & collagen XVIII alpha 1 subunit (COL18A1) & 2.71 & $\pi$ \\
\hline & collagen VI alpha 3 subunit (COLBA3) & 2.32 & $\Uparrow$ \\
\hline & collagen XI alpha 1 subunit (COL.11A1) & 2.31 & $\pi$ \\
\hline & procollagen IV alpha 2 subunit (COL4A2) & 2.22 & $\Uparrow$ \\
\hline & collagen IV alpha 8 subunit (COLAAB) & 2.10 & $\Uparrow$ \\
\hline & collagen IV alpha 3 subunit (COL4A3) & 2.05 & $\pi$ \\
\hline & laminin beta 1 subunit (laminin B1: LAMB1) & 1.48 & $\uparrow$ \\
\hline & collagen III alpha 1 subunit (COL3A1) & 1.17 & $\uparrow$ \\
\hline & procollagen II alpha 1 subunit (COL2A1) & 1.04 & $\uparrow$ \\
\hline & collagen VIII alpha 1 subunit (COL8A 1 ) & 0.88 & $\downarrow$ \\
\hline & laminin beta 2 subunit (laminin B2; LAMB2); S-laminin & 0.04 & $\downarrow$ \\
\hline & collagen I alpha 2 subunit (COL1A2) & 0.85 & $\downarrow$ \\
\hline & collagen VI alpha 2 subunit (COLBA2) & 0.74 & $\uparrow$ \\
\hline & | laminin gamma 1 subunit (LAMC1): laminin B2 subunit (LAMB2) & 0.47 & $\downarrow$ \\
\hline \multirow{12}{*}{ MMP } & $\begin{array}{l}\text { matrix metalloproteinase } 8 \text { (MMP8); neutrophil collagenase (CLG1): } \\
\text { PMNL collagenase (PMNL-CL) }\end{array}$ & 2.82 & $\pi$ \\
\hline & $\begin{array}{l}\text { PMNL collagenase (PMNL-CL) } \\
\text { matrix metalloproteinase } 15 \text { (MMP15); membrane-type matrix }\end{array}$ & 2.04 & $\pi$ \\
\hline & $\begin{array}{l}\text { metalloproteinase } 2 \text { (MT-MMP2) } \\
\text { matrix metalloproteinase } 9 \text { (MMP9); gelatinase B; } 92-\mathrm{kDa} \text { type IV }\end{array}$ & 1.87 & t \\
\hline & collagenase (CLG4B) & & \\
\hline & matrix metalloproteinase 17 (MMP17): membrane-type matrix & 1.72 & i \\
\hline & $\begin{array}{l}\text { matrix metalloproteinase } 3 \text { (MMP3): stromelysin } 1 \text { (STMY1: SL1); } \\
\text { transin } 1\end{array}$ & 1.57 & $\uparrow$ \\
\hline & $\begin{array}{l}\text { matrix metalloproteinase } 16 \text { (MMP 16): membrane-type matrix } \\
\text { metalloproteinase } 3 \text { (MT-MMP3): MMP.X2 }\end{array}$ & 1.32 & † \\
\hline & $\begin{array}{l}\text { matrix metalloproteinase } 2 \text { (MMP2): gelatinase A; } 72-k D a \text { type IV } \\
\text { collagenase (CLGAA) }\end{array}$ & 1.30 & $\uparrow$ \\
\hline & matrix metalloproteinase 1 (MMP1); interstitial collagenase (CLG): & 1.24 & † \\
\hline & & & \\
\hline & matrix metalloproteinase 13 (MMP 13): collagenase 3 (CLG3) & 1.02 & i \\
\hline & matrix metalloproteinase 12 (MMP12): metalloelastase & 0.82 & \\
\hline \multirow[t]{3}{*}{ TIMP } & tissue inhibitor of metalloproteinase 2 (TIMP2): CSC-21K & 3.01 & $\pi$ \\
\hline & $\begin{array}{l}\text { tissue inhibitor of metalloproteinase } 1 \text { (TIMP1); erythroid potentiating } \\
\text { activity protein (EPA): collagenase inhibitor (CLGI) }\end{array}$ & 2.49 & $\Uparrow$ \\
\hline & tissue inhibtor of mettaloproteinase 4 (TIMP4) & 1.00 & $\rightarrow$ \\
\hline
\end{tabular}

Table 2. Real-time PCR probe sequences and fluorescence intensities of the amplified genes

Gene

Sequence (5'-3')

GAPDH

GGGCGCCTGGTCACCAGGGCTGCTT

TTCCACCATGAAGAATCTTTGGAAG

1.000

BMP2

TGF- $\beta$ R1

CAGGTTCTGGCTCAGGTTTACCATT

FGF7

TCTATGCAAAGAAAGAATGCAATGA

EGFR

GAGCGAAGTTTTATGCAAGGGTAAC

VEGF
Intensity

$$
\begin{array}{ll}
1.975 & (p=0.013) \\
1.643 & (p=0.013) \\
1.345 & (p=0.002) \\
1.628 & (p=0.002)
\end{array}
$$

$1.532 \quad(p=0.034)$

Oligonucleotide primers and Taq man probes were designed based on sequences from the Gene Bank database. 
the threshold value, and these included genes relating to growth factors and matrix interaction, such as TGF- $\beta$ receptor type 1 (TGF- $\beta$ R1), BMP2, fibroblast growth factor 7 (FGF7), endothelial growth factor (EGFR), and vascular endothelial growth factor (VEGF). An increase of expression was also observed for the heparan sulphate and biglycan genes, whose products are extracellular matrix components, as well as the type IV and VI collagen genes. Among the genes with increased expression, genes categorized in growth factors that had the mean signal difference of greater than 1.5 fold in LIPUS treated group were compared. As a result, it was confirmed that the fluorescence intensity of the BMP2, TGF- $\beta$ R1, FGF7, EGFR, and VEGF genes was significantly increased in the LIPUS group compared with the control group (Fig. 5; Table 1).

\section{Real-time PCR}

Results of real-time PCR confirmed quantitatively that there were significant changes in the expression of the TGF- $\beta$ R1, BMP2, FGF7, EGFR, and VEGF genes after LIPUS stimulation. RNA was extracted in order to synthesize cDNA, and the fluorescence intensities of the amplified genes measured with TaqMan probes are given in Table 2.

\section{Discussion}

The use of LIPUS to noninvasively increase bioactivity is now widely applied to the treatment of fractures with non-union. LIPUS has been reported to increase the ability of cartilage cells to synthesize proteoglycans and to promote aggrecan gene expression (Paravizi et al., 1999; Zhang et al., 2002). It has also been reported that $\mathrm{Ca}^{2+}$ signalling is required to increase the synthesis of aggrecan (Paravizi et al., 2002). Further, the ability of cartilage cells to synthesize type II collagen is increased and the expression of type $\mathrm{X}$ collagen is inhibited when cartilage cells in three-dimensional culture (alginate bead encapsulation) are treated with LIPUS (Zhang et al., 2003). Since it has often been reported that apoptosis and reduced function of cells in the nucleus pulposus may trigger intervertebral disc degeneration, and it is clinically important to maintain or to upregulate the biological activity of nucleus pulposus cells, we treated nucleus pulposus cells with LIPUS to examine its potential as a noninvasive therapy for preserving the original structure and function of the intervertebral discs. The present experiment was designed to determine whether LIPUS increased the bioactivity of human nucleus pulposus cells and to examine the optimum conditions for performing LIPUS and the factors involved in activation of the cells at the gene level using the HNPSV-1 cell line established from normal human nucleus pulposus cells.

There have been several reports that LIPUS stimulates rabbit and bovine nucleus pulposus cells to synthesize proteoglycans (Miyamoto et al., 2005; Iwashina et al., 2006). Although LIPUS has a positive effect in animals, it is necessary to perform experiments on human nucleus pulposus cells before clinical application can be considered. A massive number of cells would be required to examine the optimum conditions for LIPUS. However, it is difficult to obtain the necessary number of normal human

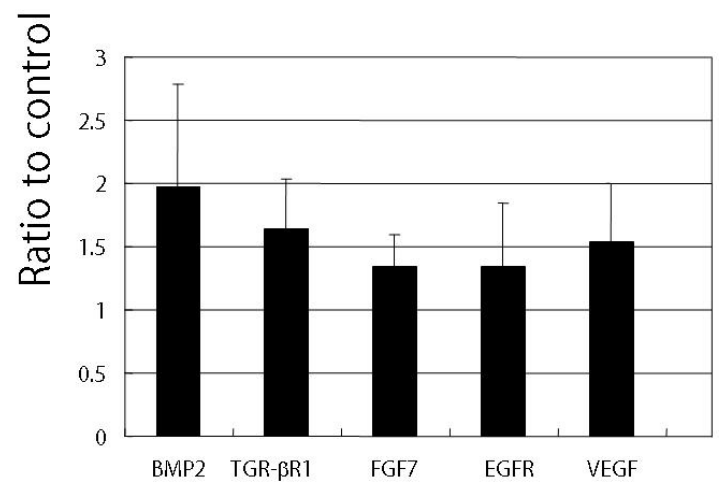

gene

Figure 6. Real time RT-PCR results confirmed upregulation of multiple growth factors in the LIPUS group compared to control group.

nucleus pulposus cells for such experiments because it is difficult to obtain nucleus pulposus tissue during surgery, and such tissue is often damaged. Therefore, the HNPSV-1 clone obtained by immortalizing normal human nucleus pulposus cells was used to examine the effect of LIPUS and the optimum conditions for its use. Since HNPSV-1 cells resemble normal human nucleus pulposus cells with respect to gene expression and matrix synthesis, use of this cell line should provide results comparable to those obtained by treating actual human nucleus pulposus cells with LIPUS.

The results of the present study showed that cell growth, as measured by $\left[{ }^{3} \mathrm{H}\right]$-thymidine incorporation, was increased in the 60 and $120 \mathrm{~mW} / \mathrm{cm}^{2}$ groups on Day 5 , although the DNA content was increased only in the 120 $\mathrm{mW} / \mathrm{cm}^{2}$ group. This may have been due to the fact that culture in alginate was more suitable for matrix synthesis than cell growth in monolayer culture. Another possible reason may have been that the proliferative activity of HNPSV-1 was already fully stimulated, in view of the original report by Sakai et al. (2004) indicating that the growth rate of HNPSV-1 cells was more than six times faster than that of normal cells.

The synthesis of proteoglycans was significantly increased in all of the treated groups compared with the control group, and the increase was particularly marked in the $30 \mathrm{~mW} / \mathrm{cm}^{2}$ group. Similarly, the DMMB assay showed that the amount of proteoglycan synthesized was significantly increased in the 15, 30, 60 and $120 \mathrm{~mW} / \mathrm{cm}^{2}$ groups on Day 5 and in all of the treated groups on Day 7 , relative to the control group. Accordingly, LIPUS may significantly increase the ability of human nucleus pulposus cells to synthesize proteoglycans and also augment the amount of proteoglycan synthesized by these cells. A previous experiment using cartilage cells in three-dimensional culture showed that LIPUS did not alter cell growth, but increased proteoglycan synthesis at 50 or $120 \mathrm{~mW} / \mathrm{cm}^{2}$ (Iwashina et al., 2006). The present study showed that LIPUS stimulated the synthesis of proteoglycans, which are important matrix components for nucleus pulposus cells, consistent with earlier data for other cell types. 
It is thought that LIPUS vibrates the extracellular matrix and thus subtly alters the pericellular environment, thereby stimulating various receptors and adhesion factors on the cell surface. A previous report that stimulation of human fibroblasts with LIPUS activated a cell adhesion factor also supports the present finding that LIPUS increased the capacity of HNPSV-1 cells to synthesize proteoglycans and also increased the amount synthesized (Zhou et al., 2004).

Iwashina et al. (2006) performed a similar study in which intervertebral disc cells from rabbits were treated with LIPUS. They showed that the proliferative activity of nucleus pulposus cells was increased only at a low intensity, and that there was no significant difference of proteoglycan synthesis between the treated and control groups during the early stage of exposure to ultrasound. In the present experiment with a human cell line, growth was increased only at high levels of ultrasound intensity, but proteoglycan synthesis was significantly increased at all intensity levels from the early stage of treatment. Since rabbit nucleus pulposus cells are heterogeneous and include many cells derived from the immature notochord, they show individual variation that tends to minimize any difference from the control group. In contrast, HNPSV-1 cells are a monoclonal cell line, and thus may respond uniformly to LIPUS.

Since it remains unknown how LIPUS stimulates the capacity of nucleus pulposus cells to synthesize proteoglycans, we investigated the mechanism responsible by the microarray technique. We found an increase in the expression of genes for small proteoglycans such as heparan sulphate and biglycan, as well as genes for growth factors that enhance disc cell activity, such as TGF- $\beta$ R1, BMP2,0FGF7, EGFR. VEGF was also found to be increased, and this has recently been reported to play a role in nucleus pulposus cell survival (Fujita et al., 2008). As growth factors like BMP2 and TGF- $\beta 1$ have already been reported to increase the synthesis of proteoglycans by nucleus pulposus cells (Yoon et al., 2003), the increased expression of such factors and their receptors suggests involvement of these genes in the increased bioactivity of nucleus pulposus cells after LIPUS stimulation.

We have not examined the effect of timing on when to apply LIPUS in this experimental series due to limited sample size. The timing factor as well as the LIPUS intensity may produce different effects.

Several studies have already investigated therapeutic techniques for increasing the activity of disc cells. Although LIPUS alone failed to provide a sufficient therapeutic effect, the present results suggest that this treatment is still worth considering for enhancement of growth factor expression, and that it in combination with other cell-stimulating techniques, merits further research. Furthermore, since there are limitations for an in vitro experiment, it is to be noted that the effect may not be as effective in vivo.

\section{Conclusions}

The present study has demonstrated that LIPUS treatment stimulates cell proliferation and production of proteoglycan in human nucleus pulposus cell line, possibly by enhance- ment of growth factor-related genes. Although the current experiment was based on in vitro research, LIPUS may be a clinically effective therapeutic technique because it is non-invasive, and can be combined with recently developed therapeutic methods to inhibit disc degeneration, possibly producing a synergistic effect.

\section{Acknowledgements}

This work was supported in part by Grant-in-Aid for Scientific Research (grant numbers 16390443, 18791060), a Grant of The Science Frontier Program from the Ministry of Education, Culture, Sports, Science and Technology of Japan, a grant from 2007 Tokai University School of Medicine Research Aid, and from AO Spine International.

\section{References}

Alini M, Li W, Markovic P, Aebi, M, Spiro R, Roughley P (2003) The potential and limitations of a cell-seeded collagen/hyaluronan scaffold to engineer an intervertebral disc-like matrix0Spine 28: 973-981.

Duarte LR (1983) The stimulation of bone growth by ultrasound. Arch Orthop Trauma Surg 101: 153-159.

Fujita N, Imai J, Suzuki T, Yamada M, Ninomiya K, Iwasaki R, Morioka H, Matsumoto M, Chiba K, Watanabe S, Suda T, Toyama Y, Miyamoto T (2008) Vascular endothelial growth factor-A is a survival factor for nucleus pulposus cells in the intervertebral disc. Biochem Biophys Res Commun 372: 367-372.

Gebauer D, Mayr E, Orthner E, Ryaby JP (2005) Low-intensity pulsed ultrasound: Effects on nonunions. Ultrasound in Med Biol 31: 1391-1402.

Gruber HE, Hanley Jr EN (1998) Analysis of aging and degeneration of the human intervertebral disc. Comparison of surgical specimens with normal controls. Spine 23: 751757.

Iwabuchi S, Ito M, Hata J, Chikanishi T, Azuma Y, Haro H (2005) In vitro evaluation of low-intensity pulsed ultrasound in herniated disc resorption. Biomaterials 26: 7104-7114.

Iwashina T, Mochida J, Miyazaki T, Watanabe T, Iwabuchi S, Ando K, Hotta T, Sakai D (2006) Low-intensity pulsed ultrasound stimulates cell proliferation and proteoglycan production in rabbit intervertebral disc cells cultured in alginate. Biomaterials 27: 354-361.

Klein RG, Eek BC, O’Neill CW, Elin C, Mooney V, Derby RR (2003) Biochemical injection treatment for discogenic low back pain: a pilot study. Spine J 3: 220-226.

Masuda K, Takegami K, An H, Kumano F, Chiba K, Andersson GB, Schmid T, Thonar E (2003) Recombinant osteogenic protein-1 upregulates extracellular matrix metabolism by rabbit annulus fibrosus and nucleus pulposus cells cultured in alginate beads. J Orthop Res 21: 922-930.

Mayr E, Frankel V, Ruter A (2000) Ultrasound-An alternative healing method for nonunions? Arch Orthop Trauma 120: 1-8.

Miyamoto K, An HS, Sah RL, Akeda K, Okuma M, Otten L, Thonar EJ, Masuda K (2005) Exposure to pulsed 
low intensity ultrasound stimulates extracellular matrix metabolism of bovine intervertebral disc cells cultured in alginate beads. Spine 30: 2398-2405.

Mizuno H, Roy AK, Vacanti CA, Kojima K, Ueda M, Bonassar LJ (2004) Tissue-engineered composites of annulus fibrosus and nucleus pulposus for intervertebral disc replacement. Spine 29: 1290-1297.

Nishida K, Kang JD, Suh JK, Robbins PD, Evans CH, Gilbertson LG (1998) Adenovirus-mediated gene transfer to nucleus pulposus cells: implication for the treatment of intervertebral disc degeneration. Spine 23: 2437-2443.

Nolte PA, Krans A, Patka P, Janssen IMC, Ryaby JP, Albers GHR (2001) Low-intensity pulsed in the treatment of nonunions. J Trauma 51: 693-702.

Paravizi J, Wu CC, Lewallen DG, Greenleaf JF, Bolander ME (1999) Low-intensity ultrasound stimulates proteoglycan synthesis in rat chondrocytes by increasing aggrecan gene expression. J Orthop Res 17: 488-494.

Paravizi J, Parpura V, Greenleaf JF, Bolander ME (2002) Calcium signaling is required for ultrasound stimulated aggrecan synthesis by rat chondrocytes. J Orthop Res 20: 51-57.

Phillips FM, An H, Kang JD, Boden SD, Weinstein J (2003) Biologic treatment for intervertebral disc degeneration. Spine 28: S99.

Sakai D, Mochida J, Yamamoto Y, Toh E, Iwashina T, Miyazaki T, Inokuchi S, Ando K, Hotta T (2004) Immortalization of human nucleus pulposus cells by a recombinant SV40 adenovirus vector: establishment of a novel cell line for the study of human nucleus pulposus cells. Spine 29: 1515-1523.

Sakai D, Mochida J, Iwashina T, Hiyama A, Omi H, Imai M, Nakai T, Ando K, Hotta T (2006) Regenerative effects of transplanting mesenchymal stem cells embedded in atelocollagen to the degenerated intervertebral disc. Biomaterials 27: 335-345.

Warden SJ, Bennell JM, McMeeken JM, Wark JD (2000) Acceleration of fresh fracture repair using the sonic accelerated fracture healing system (SAFUS): A review. Calcif Tissue Int 66: 157-163.

Yoon ST, Su Kim K, Li J, Soo Park J, Akamaru T, Elmer WA, Hutton WC (2003) The effect of bone morphogenetic protein-2 on rat intervertebral disc cells in vitro. Spine 28: 1773-1780.

Zhang ZJ, Huckle J, Francomano CA, Spencer RG (2002) The influence of pulsed low-intensity ultrasound on matrix production of chondrocytes at different stages of differentiation: an explant study. Ultrasound Med Biol 28: $1547-1553$.

Zhang ZJ, Huckle J, Francomano CA, Spencer RG (2003) The effects of pulsed low intensity ultrasound on chondrocyte viability, proliferation, gene expression and matrix production. Ultrasound Med Biol 29: 1645-1651.

Zhou S, Schmelz A, Seufferlein T, Li Y, Zhao J, Bachem MG (2004) Molecular mechanisms of low intensity pulsed ultrasound in human skin fibroblasts. J Biol Chem 24: 54463-54469.

\section{Discussion with Reviewer}

S. Ferguson: Gene expression rates were quantified by means of real-time PCR results. However, many of the genes which were considered significantly up-regulated had mean ratios of less than two. Generally, unless the authors can demonstrate extremely tight control of their PCR process, it is accepted practice to require at least a two-fold increase in gene expression before considering a difference significant.

Authors: Protocol and efficiency level of real-time PCR in this experiment has been set with appropriate controls, tight cycle condition and repeated measures. Therefore, we believe that the results are valid to determine significance. 